\title{
PERANCANGAN MODEL TATA KELOLA PENGETAHUAN PROSES INOVASI PRODUK PADA TECHNO PARK
}

\author{
Putra Fajar Alam, Asti Amalia Nur Fajrillah, Anik Hanifatul Azizah, Ahmad Almaarif \\ 1,2,3,4Program Studi Sistem Informasi, Fakultas Rekayasa Industri, Telkom University, Jl. Telekomunikasi \\ No. 1, Kawasan Pendidikan Telkom, Bandung, 40257, Indonesia
}

E-mail: putrafajaralam@telkomuniversity.ac.id, astiamalia@telkomuniversity.ac.id, anikhanifatulazizah@telkomuniversity.ac.id, ahmadalmaarif@telkomuniversity.ac.id

\begin{abstract}
Abstrak
Techno Park merupakan salah satu jenis dari organisasi/perusahaan yang membutuhkan inovasi yang berkelanjutan dalam memenuhi fungsinya sebagai lembaga riset dan komersialisasi produk. Namun hingga saat ini proses inovasi produk yang dijalankan Techno Park belum berhasil menciptakan produk yang optimal dan belum memanfaatkan pengetahuan yang tercipta di dalam proses pengembangan produk sebelumnya. Pada penelitian ini diajukan suatu model tata kelola pengetahuan untuk meningkatkan kualitas inovasi produk yang dikembangkan. Perancangan model tata kelola pengetahuan dibentuk berdasarkan sistem tata kelola COBIT 5.0 dan tata kelola pengetahuan berbasis inovasi terbuka. Untuk melihat pencapaian level kapabilitas tata kelola pengetahuan, dilakukan penilaian melalui Process Assesement berdasarkan model tata kelola pengetahuan yang telah disusun. Proses riset dan komersialisasi adalah fokus utama dalam pembentukan model tata kelola pengetahuan pada Techno Park. Proses - proses pendukung seperti peningkatan jejaring serta proses inkubasi start-up juga diperhatikan peranannya dalam mendukung proses riset dan pengembangan bisnis. Tujuan yang ingin dicapai dari penelitian ini adalah membuat model tata kelola pengetahuan pada proses inovasi produk di Techno Park. Hasil dari penelitian ini berupa model tata kelola dengan 3 komponen berupa: enabler tata kelola pengetahuan; lingkup tata kelola pengetahuan; peran, aktivitas dan tata kelola pengetahuan. Model ini diharapkan dapat membantu Techno Park untuk menciptakan produk inovasi yang lebih optimal dengan memanfaatkan pengelolaan pengetahuan yang tercipta sebelumnya melalui suatu model tata kelola pengetahuan. Perlu dilakukan penelitian lanjutan untuk meningkatkan efektifitas model agar semakin relevan dengan tujuan pengembangan produk inovasi pada Techno Park.
\end{abstract}

Kata kunci :

Techno Park, riset \& komersialisasi, tata kelola pengetahuan

\begin{abstract}
Techno Park is an organization in need of continuous innovation because of it functions a research facility and product's commercialization. To date, their products of innovations haven't successfully been commercialized. Their product isn't being optimized properly. They also not utilizing their previous knowledge of developing product fully yet. This research proposed a knowledge governance model to increase the quality of product that being developed. The model is designed based on COBIT 5.0 governance system and an open innovation based of knowledge governance. To see an achievement level of knowledge governance's capability a rating is made. The rating made through Assessment Process based on knowledge governance system that has been made earlier. Research process and commercialization is the main focus in making a knowledge governance system on Techno Park. Other supporting process such as networking and start-up incubation is also observed closely of their role in research support and business development. The objective of this research is to create a model of knowledge governance in product innovation process in Techno Park. The result of this research in form of governance model with 3 components: the enablers of knowledge governance; the scope of knowledge governance; role and activity of knowledge governance. This model is expected to help Techno Park to create a more optimized product innovation by utilizing the knowledge management that was created before through a model of knowledge governance. Further research is needed to improve the effectiveness of the model to be more relevant to the purpose of innovation product development in Techno Park.
\end{abstract}


Keywords:

Techno Park, research \& commercialization, knowledge governance

\section{Pendahuluan}

Techno Park adalah sebuah organisasi yang dikelola oleh para professional dengan tujuan utama organisasi untuk meningkatkan kesejahteraan masyarakat melalui penguatan dan peningkatan budaya inovasi serta meningkatkan daya saing perusahaan dan lembaga (Moudi, 2011). Melalui Techno Park, proses riset dan komersialisasi produk diharapkan dapat memberikan nilai tambah serta membawa kemandirian teknologi bagi kemajuan bangsa melalui produk - produk inovasi yang dikembangkan serta menciptakan sinergi antara unsur ABGC (Academic, Business, Government, Community).

Penanganan atau pemanfaatan pengelolaan pengetahuan untuk menciptakan sinergi antara pengetahuan yang berbeda dapat menciptakan peningkatan inovasi yang berkelanjutan (Desouza \& Awazu, 2006). Dengan adanya inovasi yang berkelanjutan, Techno Park dapat menciptakan produk dengan peningkatan yang berkelanjutan seiring dengan kebutuhan akan produk inovatif berkualitas bagi penggunanya. Hingga saat ini belum ada strategi pengelolaan pengetahuan yang berkelanjutan dalam proses inovasi produk pada Techno Park. Hal ini yang menjadi dasar diperlukannya strategi tata kelola pengetahuan agar tujuan pemanfaatan pengetahuan ini dapat tercapai secara optimal.

Penelitian ini bertujuan untuk mengembangkan model tata kelola pengetahuan agar meningkatkan kualitas inovasi produk pada suatu Techno Park. Untuk menilai tingkat kualitas inovasi produk, pengembangan model tata kelola dalam penelitian ini dilakukan dengan pendekatan framework COBIT 5.0 (Control Objectives for Information and Related Technology). Level kapabilitas inovasi produk yang telah dicapai dapat dibandingkan dengan target yang diinginkan. Dengan model ini, setiap saat Techno Park dapat mengukur pencapaian tingkat kapabilitas dan target yang dikehendaki. Selisih antara kedua level tersebut dapat menjadi acuan dalam menentukan strategi peningkatan proses kualitas inovasi produk dengan menggunakan model tata kelola pengetahuan yang berkembang seiring pertumbuhan suatu Techno Park.
Tujuan yang ingin dicapai dari penelitian ini adalah membuat model tata kelola pengetahuan pada proses inovasi produk di Techno Park. Model ini diharapkan dapat membantu Techno Park untuk menciptakan produk inovasi yang lebih optimal dengan memanfaatkan pengelolaan pengetahuan yang tercipta sebelumnya melalui suatu model tata kelola pengetahuan.

\section{Tinjauan Pustaka}

\section{II.1 Definisi Pengetahuan}

Dalam upaya mencapai keunggulan kompetitif, manajemen pengetahuan merupakan faktor yang paling penting bagi organisasi saat ini. Pengetahuan adalah informasi yang mengubah sesuatu atau seseorang, hal itu terjadi ketika informasi tersebut menjadi dasar untuk bertindak, atau ketika informasi tersebut memampukan seseorang atau institusi untuk mengambil tindakan yang berbeda atau tindakan yang lebih efektif (Tobing, 2007). Pengetahuan bergantung pada data dan informasi yang dimiliki oleh suatu personal yang merefleksikan tentang suatu pendapat.

Gagasan yang mendasari pengertian pengetahuan adalah sebagai berikut (Choo, 1998):

1. Pengetahuan merupakan kepercayaan yang dapat dipertanggungjawabkan (justified true believe).

2. Pengetahuan merupakan sesuatu yang explicit sekaligus tacit.

3. Penciptaan pengetahuan secara efektif bergantung pada konteks yang memungkinkan terjadinya penciptaan tersebut.

Penciptaan pengetahuan melibatkan lima langkah utama, yaitu berbagi pengetahuan terbatinkan, menciptakan konsep, membenarkan konsep, membangun prototype, dan melakukan penyebaran pengetahuan di berbagai fungsi dan tingkat organisasi.

Pengetahuan merupakan informasi yang dikombinasikan dengan pengalaman serta penilaian. Secara umum terdapat dua jenis pengetahuan (Nonaka \& Takeuchi, 1995), yaitu:

1. Explicit knowledge adalah pengetahuan yang terdokumentasikan dalam berbagai bentuk, seperti paper, laporan penelitian, buku, artikel, manuskrip, paten dan software, dan lain-lain. Dengan kata lain pengetahuan yang sudah dapat dikemukakan dalam bentuk data, formula, spesifikasi produk, manual, prinsipprinsip umum, dan sebagainya. Pengetahuan jenis ini dapat segera diteruskan dari satu 
individu ke individu lain secara formal dan sistematis.

2. Tacit knowledge, berasal dari kata tacit berarti sesuatu yang tidak dengan mudah dilihat dan diekspresikan. Tacit knowledge berakar dalam tindakan dan pengalaman pribadi, seperti dambaan, nilai, atau pun emosi. Wawasan dan intuisi subjektif juga masuk dalam kategori ini. Tacit knowledge sangat bersifat pribadi dan sulit diformalisasikan.

\section{II.2 Definisi Manajemen Pengetahuan}

Manajemen pengetahuan atau knowledge management $(\mathrm{KM})$ ialah strategi dan proses yang dirancang untuk mengidentifikasi, menangkap, menyusun, menambah nilai, memberikan pengaruh, dan berbagi aset intelektual organisasi untuk meningkatkan kinerja dan daya saing. Knowledge Management (KM) / Manajemen Pengetahuan terkait dengan aktivitas memfasilitasi pengelolaan pengetahuan, antara lain melalui aktivitas penciptaan pengetahuan, menangkap pengetahuan, perubahan serta penggunaan pengetahuan. Hal ini didasarkan pada dua aktivitas penting, yaitu (1) menangkap dan mendokumentasikan pengetahuan tacit dan explicit individu dan (2) menyebarkannya dalam organisasi (Rahmatia, 2013). Istilah manajemen pengetahuan pertama kali diperkenalkan kira-kira pada awal tahun 1990-an.

Pengertian lain dari manajemen pengetahuan adalah pengelolaan pengetahuan perusahaan dalam menciptakan nilai bisnis (business value) dan menghasilkan keunggulan kompetitif yang berkesinambungan (sustainable competitive advantage) dalam mengoptimalkan proses penciptaan, pengomunikasian dan pengaplikasian semua pengetahuan yang dibutuhkan dalam rangka pencapaian tujuan bisnis (Tobing, 2007).

Dari pernyataan tersebut $K M$ harus mendukung tujuan jangka panjang institusi untuk senantiasa memiliki keunggulan kompetitif yang berkesinambungan. Fokus manajemen pengetahuan adalah penentuan, pengorganisasian, pengarahan, memfasilitasi, dan pemantauan pengetahuan terkait dengan praktik dan aktivitas yang diperlukan untuk mencapai strategi dan tujuan organisasi yang diinginkan (Wiig, 1999). Meskipun definisinya berbeda-beda, dapat ditarik pengertian bahwa manajemen pengetahuan menekankan:

1. Adanya usaha yang serius untuk meningkatkan sistem kognisi (organisasi, manusia, teknologi, atau gabungan manusia dan teknologi).

2. Adanya aset-aset pengetahuan yang dikelola, yang berasal dari dalam dan luar organisasi, individu atau kelompok.

3. Adanya proses pengadaan, pengolahan, penyimpanan, dan penggunaan pengetahuan tersebut untuk mencapai tujuan tertentu.

4. Adanya penyebaran pengetahuan dan pengalaman baik melalui akses langsung ke basis data maupun melalui sharing dan kolaborasi ke lingkungan internal dan eksternal organisasi.

5. Adanya kreativitas dan inovasi menciptakan pengetahuan baru.

6. Adanya pengelolaan penciptaan pengetahuan (knowledge creation) dan pengorganisasian pengetahuan.

Untuk mencapai KM yang efektif, terdapat empat proses yang harus berjalan secara berkelanjutan. Berikut ini adalah penjelasan dari keempat proses tersebut (Alavi \& Leidner, 2001).

\section{a. Knowledge Creation}

Sebelum dikelola, pengetahuan harus dibentuk terlebih dahulu. Nonaka bersama Takeuchi membuat sebuah model bernama SECI yang merupakan model proses pembentukan pengetahuan (knowledge creation) untuk memahami sifat dinamis dari proses tersebut (Nonaka \& Takeuchi, 2000).

SECI merupakan singkatan dari Socialization, Exernalization, Combination, dan Internalization yang didefinisikan sebagai berikut.

1. Socilization

Socialization adalah proses pembentukan pengetahuan dari bentuk tacit ke bentuk tacit. Dapat dikatakan bahwa proses ini adalah proses berbagi pengetahuan dalam bentuk lisan antar individu.

2. Externalization

Externalization adalah proses pembentukan pengetahuan dari bentuk tacit ke bentuk explicit. Proses ini terjadi saat individu memindahkan pengetahuan yang ia miliki ke dalam suatu media penyimpanan.

3. Combination

Combination adalah proses pembentukan pengetahuan dari bentuk explicit ke bentuk explicit. Berbagi file antara satu komputer dengan komputer lain merupakan salah satu bentuk kombinasi. 
4. Internalization

Internalization adalah proses pembentukan pengetahuan dari bentuk explicit ke bentuk tacit. Proses ini berlangsung ketika individu mendapatkan pengetahuan dari suatu media penyimpanan.

a. Knowledge Storage and Retrieval

Ingatan organisasi meliputi pengetahuanpengetahuan yang berada dalam berbagai bentuk, termasuk dokumentasi tertulis, informasi terstruktur yang disimpan dalam basis data elektronik, pengetahuan manusia terkodifikasi yang disimpan dalam sistem pakar, proses dan prosedur organisasi yang didokumentasikan, serta pengetahuan tacit yang diperoleh dari individu dan jaringannya.

b. Knowledge Distribution

Transfer pengetahuan dapat dilakukan pada tingkatan yang berbeda-beda, diantaranya antarindividu, dari individu ke kelompok, antarkelompok, dan dari kelompok ke organisasi. Dengan mempertimbangkan pengetahuan organisasi yang terdistribusi secara alamiah, suatu proses yang penting dari KM adalah transfer pengetahuan ke lokasi dimana pengetahuan tersebut dibutuhkan dan digunakan.

c. Knowledge Application

Sumber keunggulan kompetitif terletak pada penerapan pengetahuan daripada pengetahuan itu sendiri. Terdapat tiga mekanisme utama dalam integrasi pengetahuan, yaitu arahan, rutinitas organisasi, dan tim mandiri yang dijelaskan sebagai berikut.

1. Arahan mengacu pada sekumpulan aturan, ukuran, prosedur, dan instruksi spesifik yang dikembangkan melalui konversi dari para spesialis. Pengetahuan tacit diubah menjadi pengetahuan eksplisit dan terpadu untuk komunikasi yang efisien bagi non-spesialis.

2. Rutinitas organisasi mengacu pada pengembangan kinerja dari tugas dan pola koordinasi, protokol interaksi, dan spesifikasi proses yang memungkinkan individu untuk menerapkan dan mengintegrasikan pengetahuan mereka tanpa perlu mengkomunikasikan apa yang mereka ketahui kepada orang lain.

3. Mekanisme integrasi pengetahuan yang terakhir adalah pembentukan tim mandiri untuk melaksanakan tugas. Dalam situasi di mana ketidakpastian dan kompleksitas tugas menghalangi spesifikasi arahan dan rutinitas organisasi, tim dari individu-individu dengan pengetahuan prasyarat dan khusus dibentuk untuk memecahkan masalah.

\section{II.3 Knowledge Governance}

Berdasarkan referensi buku Knowledge Governance: Processes \& Perspectives (Foss \& Michailova, 2009) bermacam argumen baik yang berasal dari penelitian maupun dari praktik keseharian, memberikan kontribusi signifikan bagi perkembangan konsep pengelolaan pengetahuan selama dekade ini. Banyak yang mengklaim bahwa era saat ini adalah era knowledge economy, yang merupakan suatu bentuk ilmu yang digunakan untuk menangkap fenomena dan kecenderungan penting yang sedang terjadi. Diantara kecenderungan tersebut, yang merupakan peningkatan nilai dari pemikiran manusia, ada suatu peningkatan penting dari sisi aset immaterial dan pengetahuan di bidang sains, serta keperluan untuk mengendalikan pertumbuhan pemanfaatan teknologi dan perlunya peningkatan jumlah pengetahuan, tidak hanya untuk internal perusahaan, tetapi juga dengan aliansi/afiliasi serta jejaring yang dimiliki suatu perusahaan/organisasi (Foss \& Michailova, 2009).

Buku ini menjelaskan bahwa tata kelola pengetahuan bertujuan untuk menentukan tujuan organisasi, arahan, batasan, dan akuntabilitas dari organisasi tersebut. Pembahasan ini terbagi menjadi topik - topik mendasar yang berkaitan dengan cara mengelola penciptaan pengetahuan yang berkaitan dengan perspektif problem-finding dan problemsolving, arsitektur organisasi pengetahuan, poliarki tata kelola \& pertumbuhan pengetahuan, otoritas manajemen ketika pengetahuan didistribusikan, tata kelola produksi pengetahuan, proses penciptaan dan pembagiannya pada organisasi, dan prinsip utama tata kelola, mekanisme dan taktik yang dapat diterapkan untuk berbagai macam use case, serta sebuah ide tentang tata kelola pengetahuan.

\section{II.4 Knowledge Management System (KMS)}

Knowledge Management System merupakan metode yang bisa menjamin proses pengelolaan $K M$ berjalan. Definisi knowledge management system (KMS) mengacu pada sebuah kelas sistem informasi yang diterapkan untuk mengelola pengetahuan organisasi (Alavi \& Leidner, 2001). Artinya, sistem berbasis IT (IT-based system) yang dikembangkan untuk mendukung dan meningkatkan proses penciptaan pengetahuan organisasi, penyimpanan, pengalihan, dan aplikasi. Fungsi dari knowledge system adalah menyusun dan menyimpan knowledge baik yang berupa tacit maupun explicit tersebut 
sehingga dapat digunakan kembali saat dibutuhkan Dengan pemanfaatan teknologi informasi yang dapat mendukung proses tersebut.

Proses knowledge management system merupakan IT-based system yang dibangun untuk mendukung dan mengembangkan knowledge yang ada di organisasi. Peranan dan tujuan dari knowledge management system adalah sebagai berikut:

1. Sarana pengumpulan knowledge

Knowledge management system berguna sebagai sarana untuk mengumpulkan knowledge bagi organisasi. Proses pengumpulan knowledge ini dapat berasal dari mana saja dan dapat pula berbentuk apa saja baik tacit maupun explicit.

2. Sarana penyebaran knowledge

Knowledge management system adalah sarana untuk saling tukar-menukar knowledge yang ada dari satu entitas ke entitas lain. Juga sebagai sarana transfer knowledge sehingga masingmasing entitas dapat memiliki knowledge yang sebelumnya dimiliki.

\section{Sarana pengelolaan knowledge}

Knowledge management system juga beguna sebagai tempat penyimpanan knowledge (dalam bentuk database misalnya) dan mengelolanya sehingga knowledge yang ada dan telah tersimpan tidak terbengkalai begitu saja.

4. Meningkatkan knowledge

Knowledge management system juga berguna sebagai sarana meningkatkan knowledge yang ada dengan cara memilah knowledge mana yang dapat berperan dalam proses upgrading dari knowledge tiap entitas dalam organisasi.

Seperti pada kebanyakan area di bidang pengembangan sistem informasi, di $K M$ pun tidak terlepas dari 3 elemen utama KM, yaitu: People, Process, Technology (Wickramasinghe, 2006). Ketiganya merupakan tiga elemen penting yang dapat menentukan keberhasilan implementasi sistem $K M$. Bahkan dikatakan bahwa knowledge management itu sendiri adalah integrasi dari people dan process, yang kemudian dimungkinkan dengan technology, untuk memfasilitasi pertukaran informasi, knowledge, dan keahlian untuk meningkatkan kinerja organisasi.

Hubungan di antara ketiga elemen tersebut dinamakan KM Triad seperti yang ditunjukkan pada Gambar II.1 KM Triad adalah untuk menekankan bahwa knowledge dapat diciptakan oleh orang dan atau teknologi dan juga dapat tertanam dalam suatu proses.

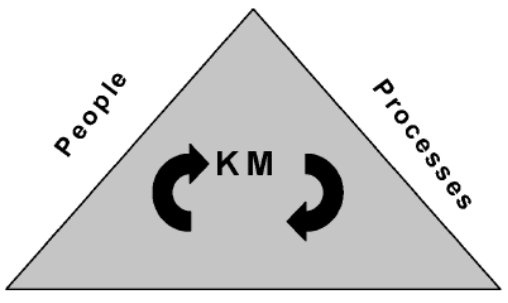

Technologies

Gambar 1 KM Triad

\section{II.5 Knowledge Management Lifecycle}

Proses dari knowledge management system merupakan IT-based system yang dibangun untuk mendukung dan mengembangkan knowledge yang ada di organisasi. Knowledge management lifecycle dapat diterapkan pada konteks teknologi informasi dari sistem knowledge management. Berdasarkan model siklus knowledge management lifecycle terdapat empat tahapan yaitu creation, storage, transfer, dan application (Alavi \& Leidner, 2001).

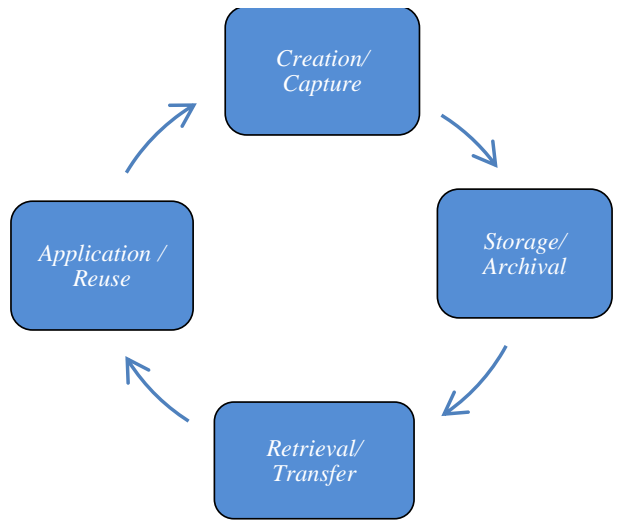

Gambar II.2 Knowledge Management Lifecycle (Alavi \& Leidner, 2001)

Proses creation adalah proses identifikasi knowledge yang ada di perusahaan, serta usaha memunculkan knowledge baru dari proses pembelajaran. Model ini menyadari bahwa knowledge creation di organisasi melibatkan interaksi yang berkelanjutan di antara tacit dan explicit knowledge serta bergerak secara spiral ketika knowledge berpindah melalui individu, kelompok, dan organisasi.

Proses creation diikuti oleh proses storage atau retrieval, yaitu kegiatan penyimpanan knowledge ke 
dalam bentuk yang dapat dengan mudah diakses dan diambil lagi pada lain waktu.

Proses berikutnya adalah pengambilan dan transfer knowledge yang telah tersimpan dalam basis knowledge, baik itu antara individu, kelompok, organisasi, ataupun dari dokumen yang tersimpan. Proses application merupakan proses pengaplikasian dari knowledge hingga knowledge bisa digunakan. Menurut (Alavi \& Leidner, 2001), aspek penting dari teori berbasis knowledge dari suatu organisasi adalah bahwa sumber dari keunggulan kompetitif berada dalam knowledge application dan bukan dalam pengetahuan itu sendiri. Dalam hal ini peran teknologi dapat mendukung knowledge application dengan melekatkan pengetahuan ke dalam rutinitas organisasi.

Berdasarkan model siklus dari (Alavi \& Leidner, 2001) dapat disimpulkan bahwa knowledge management lifecycle dapat diterapkan pada konteks teknologi informasi dari sistem knowledge management.

\section{II.6 Manfaat Manajemen Pengetahuan}

Pada prinsipnya manfaat dari konsep manajemen pengetahuan adalah untuk meningkatkan kinerja organisasi. Manfaat dari manajemen pengetahuan sebagai berikut:

1. Menciptakan suatu pengetahuan yang dapat diterima oleh berbagai pihak dan dapat digunakan dalam konteks pembelajaran.

2. Memfasilitasi pengumpulan, perekam, pengorganisasian, penyaringan, analisi dan penyebaran pengetahuan eksplisit dan implisit. Pengetahuan yang dimaksud terdiri dari prosedur informal yang tidak terdokumentasi, seluruh dokumen dan data yang disimpan di komputer. Informasi ini harus secara menyeluruh dan dengan mudah tersedia untuk kelangsungan organisasi.

\section{II.7 Perbedaan Tata Kelola Pengetahuan dan Manajemen Pengetahuan}

Manajemen adalah pengalokasian dari sumber daya dan pengendalian terhadap kegiatan sehari - hari dari organisasi/perusahaan. Manajemen juga membahas mengenai melakukan sesuatu dengan cara - cara yang seharusnya.
Sedangkan tata kelola adalah tugas/kegiatan strategis untuk menentukan tujuan organisasi, arahan, batasan, dan akuntabilitas dari organisasi tersebut. Tata kelola dapat dikatakan sebagai kebijakan dan prosedur untuk memastikan bahwa suatu pekerjaan diselesaikan dengan cara yang benar dan tepat.

\section{II.8 Tata Kelola Pengetahuan untuk Inovasi Terbuka}

Penelitian Tata Kelola Pengetahuan untuk Inovasi Terbuka menggunakan kolaborasi R\&D sebagai konteks pembelajarannya. Suatu studi empiris mendiskusikan tantangan yang berbeda sebagai suatu pendekatan terbuka untuk mencapai proses inovasi pada tata kelola pengetahuan (Scarbrough \& Edelman, 2004). Tantangan ini, berjalan diatas suatu masalah yang menyatakan bahwa penyerapan pengetahuan terjadi berdasarkan inovasi terbuka yang melibatkan parameter kualitatif yang membuat, mengeksploitasi, dan mengorganisasikan pengetahuan.

Hal ini memiliki implikasi yang luas untuk dasar pengetahuan itu sendiri yang pada akhirnya, suatu inovasi yang terbuka memberikan dampak berkurangnya ketergantungan fungsi internal dalam R\&D dan memunculkan keinginan untuk melakukan pertukaran pengetahuan dengan kolaborasi eksternal. Dalam konteks yang lebih luas, hal ini dapat berarti perubahan terhadap struktur dan praktik manajemen untuk menciptakan interaksi yang lebih bagus dengan suatu ekosistem penyedia pengetahuan yang lebih besar.

Selain itu dibahas pula dilema antara stabilitas dan perubahan bentuk tata kelola yang diadopsi. Melalui pengujian terhadap mega proyek Uni Eropa MOZART, (Scarbrough \& Edelman, 2004) disimpulkan bahwa karena pengetahuan di proses secara sporadis dan terkadang tak menentu dari pengetahuan yang ada ke pengetahuan yang baru, hal tersebut sulit untuk menciptakan suatu solusi tata kelola yang berkelanjutan untuk keseluruhan prosesnya.

\section{II.9 COBIT 5.0}

COBIT 5.0 membantu perusahaan menciptakan nilai yang optimal dari pemanfaatan IT dengan menjaga keseimbangan antara perwujudan manfaat dan mengoptimalkan tingkat risiko dan penggunaan sumber daya (ISACA, 2012). COBIT 5.0 memungkinkan informasi dan teknologi yang terkait untuk diatur dan dikelola secara menyeluruh untuk keseluruhan perusahaan, mencakup seluruh proses 
bisnis dan tanggung jawab area fungsional serta mempertimbangkan keterkaitan IT dengan pemangku kepentingan internal dan eksternal. Prinsip dan enabler COBIT 5.0 berguna untuk perusahaan segala jenis dan ukuran, baik yang komersil maupun nonprofit.

Hubungan antara prinsip, sistem tata kelola, dan PAM COBIT 5.0 dapat dijelaskan sebagai berikut:

1. 5 Prinsip COBIT 5.0 (memenuhi kebutuhan pemangku kepentingan, melingkupi seluruh perusahaan, menerapkan satu kerangka kerja terintegrasi, menggunakan pendekatan holistic, dan memisahkan tata kelola dengan manajemen) menjadi dasar bagi sistem tata kelola COBIT 5.0.

2. Komponen utama dalam sistem tata kelola (tujuan tata kelola, enablers tata kelola, lingkup tata kelola, dan peran, aktivitas, \& hubungan) merupakan perwujudan dari 5 prinsip COBIT 5.0, khususnya prinsip menggunakan pendekatan holistik/menyeluruh dan memisahkan tata kelola dengan manajemen.

3. Level kapabilitas proses merupakan bentuk penilaian pencapaian kapabilitas proses, yang mana proses ini dapat memberikan gambaran bagi organisasi/perusahaan untuk melihat tingkat pencapaian saat ini, penentuan target yang akan dicapai, serta melihat kesenjangan antara dua hal tersebut. Dengan menggunakan level kapabilitas proses, organisasi/perusahaan akan mampu menurunkan/menterjemahkannya menjadi target - target yang perlu dicapai baik dalam jangka pendek maupun jangka panjang.

\section{ANALISIS DAN PERANCANGan Model Tata Kelola Pengetahuan}

Hasil analisis pada kajian ini menjadi dasar usulan model tata kelola pengetahuan proses inovasi produk pada Techno Park. Perancangan model tata kelola pengetahuan dibentuk berdasarkan 12-tahap proses manajemen pengetahuan, sistem tata kelola COBIT 5.0 dan tata kelola pengetahuan berbasis inovasi terbuka. Proses manajemen pengetahuan memberikan gambaran mengenai proses, aktivitas, dan work product manajemen pengetahuan. Sistem tata kelola COBIT 5.0 memberikan cara pendekatan tata kelola secara menyeluruh (ISACA, 2012). Tata kelola pengetahuan berbasis inovasi terbuka memberikan gambaran elemen - elemen proses tata kelola pengetahuan pada perusahaan berbasis inovasi terbuka. Untuk melakukan penilaian pencapaian proses, digunakan cara penilaian kapabilitas dari COBIT 5.0 Process Assesment Model (PAM).

\section{III.1 Analisis Manajemen Pengetahuan}

Penelitian mengenai proses manajemen pengetahuan menghasilkan 12 tahap proses dan aktivitas untuk membuat dan mengimplementasikan manajemen pengetahuan secara optimal pada organisasi/perusahaan. Hasil analisis terhadap penelitian tersebut diuraikan berdasarkan 4 pilar utamanya sebagai berikut.

\section{III.1.1 Pilar Kepemimpinan}

Pengetahuan dan manajemen pengetahuan bukanlah sebuah konsep baru. Hal ini didasari pemikiran bahwa bisnis sudah memahami pentingnya mengelola pengetahuan yang mereka miliki dan mengubahnya menjadi suatu informasi yang berguna. Pilar ini terdiri dari 4 proses berikut:

1. Melakukan identifikasi pengetahuan kritis Tahapan pertama adalah proses identifikasi pengetahuan kritikal yang harus dikelola.

2. Melakukan analisis berdasarkan kinerja

Tahap kedua adalah proses analisis berbasis kinerja yang berfokus pada area permasalahan utama. Analisis ini terdiri dari topik :
a. Profil pelanggan
b. Produk
c. Bisnis
d. Proses
e. Peserta
f. Informasi
g. Teknologi

3. Menyampaikan rencana aksi tingkat tinggi pada manajemen

Pada umumnya tahapan ini merupakan tahapan paling sulit, dimana dibutuhkan suatu teknik untuk meyakinkan dan menjelaskan manajemen serta apa keuntungan yang didapat jika melakukan manajemen pengetahuan. Ada banyak persiapan yang harus dihasilkan yaitu : estimasi, rencana kerja dan manajemen sumber daya.

\section{III.1.2 Pilar Organisasi}

Kesuksesan implementasi pada proses ini bergantung pada pemilihan sistem yang akan digunakan dan tidak digunakan. Tahap perancangan dan persyaratan harus memenuhi apa yang dibutuhkan oleh pengguna, tidak hanya fokus pada 
teknologi yang digunakan. Pilar ini terdiri dari 4 proses berikut:

1. Merangkul para pemangku kepentingan utama

2. Mengembangkan model proses

3. Mengidentifikasi kesenjangan, peluang, dan risiko pengetahuan yang kritikal

4. Menentukan tujuan prioritas

5. Mengembangkan program persyaratan dan pengukuran

\section{III.1.3 Pilar Teknologi}

Pilar ini terdiri dari 4 proses berikut:

1. Merencanakan pendekatan strategi tingkat tinggi

2. Melaksanakan strategi implementasi

3. Memantau, mengukur, dan melaporkan metrik

\section{III.1.4 Pilar Pembelajaran}

Fokus pada tahap ini adalah pembelajaran terhadap proyek - proyek atau kegiatan yang pernah dilakukan. Selain itu hal yang perlu diperhatikan adalah hasil artefak dari kegiatan tersebut.

\section{III.2 Analisis Tata Kelola Manajemen} Pengetahuan

Pada suatu studi empiris yang dilakukan oleh (Scarbrough \& Edelman, 2004), dilakukan penelitian mengenai tantangan yang berbeda sebagai suatu pendekatan terbuka untuk mencapai proses inovasi pada tata kelola pengetahuan.

Penelitian ini berhasil melakukan identifikasi 3 (tiga) tantangan untuk mencapai proses inovasi pada tata kelola pengetahuan, yaitu:

\section{III.2.1 Mekanisme Tata Kelola Pengetahuan}

Mekanisme tata kelola pengetahuan yang diadopsi untuk inovasi terbuka pada umumnya berkembang dari waktu ke waktu, dengan beberapa faktor ketergantungan pada evolusinya (Scarbrough \& Edelman, 2004). Namun begitu, kondisi awal tata kelola cenderung akan memberikan pengaruh pada perkembangan seterusnya. Mekanisme ini terdiri dari faktor sebagai berikut :

1. Pemilihan rekan

2. Mekanisme formal dan relasional

3. Lingkup aktivitas kolaborasi

\section{III.2.2 Proses Pengetahuan}

Inovasi terbuka akan terjadi paling mudah integrasinya ketika pengetahuan dibentuk secara modular dan berbentuk eksplisit (Scarbrough \& Edelman, 2004). Sebaliknya, ketergantungan pada tacit knowledge akan lebih sulit diakomodir dalam proses inovasi terbuka mengingat kompleksitas mekanisme tata kelola yang dibutuhkan. Hal tersebut diterjemahkan menjadi faktor berikut :

1. Interdependensi tugas

2. Modularitas pengetahuan

3. Ketergantungan bentuk pengetahuan tacit/explicit

\section{III.2.3 Hubungan antar-unit}

Pada proses inovasi terbuka yang lebih membutuhkan integrasi tacit knowledge, hal ini hanya akan tercapai jika ada suatu mekanisme relasional yang kuat antara para peserta/pihak yang terlibat di dalam jaringan tersebut (Scarbrough \& Edelman, 2004). Atas dasar hal tersebut, dalam hubungan antar unit terdiri dari faktor berikut:

1. Unsur sosial

2. Peluang/Risiko

3. Kekuatan/Kelemahan

III.2.4 Manfaat Tata Kelola Pengetahuan berbasis Inovasi Terbuka

Perancangan model tata kelola pengetahuan dibentuk berdasarkan 12-tahap proses manajemen pengetahuan, sistem tata kelola COBIT 5.0 dan tata kelola pengetahuan berbasis inovasi terbuka. Proses manajemen pengetahuan memberikan gambaran mengenai proses, aktivitas, dan work product manajemen pengetahuan. Sistem tata kelola COBIT 5.0 memberikan cara pendekatan tata kelola secara menyeluruh (ISACA, 2012). Tata kelola pengetahuan berbasis inovasi terbuka memberikan gambaran elemen - elemen proses tata kelola pengetahuan pada perusahaan berbasis inovasi terbuka. Untuk melakukan penilaian pencapaian proses, digunakan cara penilaian kapabilitas dari COBIT 5.0 Process Assessment Model (PAM).

\section{III.3 Analisis Sistem Tata Kelola COBIT 5.0}

Fokus penelitian ini adalah membentuk model tata kelola pengetahuan pada proses inovasi produk dengan menggunakan sistem tata kelola COBIT 5.0. Sistem tata kelola ini terdiri dari :

\section{III.3.1 Tujuan Tata Kelola}

Tahap ini berguna untuk menentukan tujuan tata kelola yaitu penciptaan nilai. Dalam hal ini untuk 
mendukung terciptanya proses inovasi produk yang optimal, tujuan tata kelola yang ingin dicapai adalah penciptaan nilai pengetahuan. Selain itu dalam tahap ini juga diperhatikan perwujudan manfaat melalui optimalisasi risiko dan penggunaan sumber daya.

\section{III.3.2 Enablers Tata Kelola}

Enablers Tata Kelola adalah sumber daya organisasi untuk melakukan tata kelola, seperti kerangka kerja, prinsip, struktur, proses/mekanisme, dan cara praktik, melalui suatu tindakan yang diarahkan dan dapat tercapai tujuannya (ISACA, 2012). Dalam hal ini, enablers proses tata kelola adalah mekanisme yang berkaitan dengan proses inovasi produk. Kapabilitas layanan (infrastruktur IT, aplikasi, dll), orang dan informasi juga termasuk dalam sumber daya enablers. Penggunaan kakas, aplikasi serta pemanfaatan infrastruktur IT lainnya menjadi parameter dalam penilaian kapabilitas proses.

\section{III.3.3 Lingkup Tata Kelola}

Tata kelola dapat diterapkan untuk seluruh entitas perusahaan, baik yang berwujud maupun tidak (ISACA, 2012). Hal ini berarti sangat mungkin untuk mendefinisikan pandangan yang berbeda pada penerapan tata kelola di dalam perusahaan. Dan juga sangat penting untuk menentukan lingkup agar sistem tata kelola berjalan dengan baik. Dalam hal ini, lingkup tata kelola yang dijadikan fokus dalam penelitian adalah bentuk pengetahuan yang berupa tacit/explicit dan modularitas pengetahuan. Fokus ini bertujuan agar penilaian kapabilitas mampu melihat tingkat pemanfaatan pengetahuan yang tercipta dari proses - proses inovasi produk sebelumnya.

\section{III.3.4 Manfaat membuat Tata Kelola menggunakan COBIT 5.0}

Unsur terakhir adalah peran, aktivitas, dan hubungan tata kelola. Hal ini mendefinisikan siapa yang terlibat, cara/bagaimana mereka terlibat, kapan dan bagaimana mereka berinteraksi, dalam lingkup sistem tata kelola (ISACA, 2012). Pada proses inovasi produk, perlu didefinisikan dengan jelas siapa yang terlibat, cara/bagaimana mereka terlibat, kapan dan bagaimana mereka berinteraksi. Selain itu, pada proses inovasi produk perlu dipertegas perbedaan antara aktivitas dan domain/unit tata kelola dan manajemen, serta keterhubungan antara pihak - pihak yang terlibat. Hal ini merupakan manfaat penggunaan COBIT 5.0 dalam proses pembuatan Tata Kelola.

\section{III.4 Rancangan Model Tata Kelola} Pengetahuan Proses Inovasi Produk

Berdasarkan hasil studi pustaka, sistem tata kelola COBIT 5.0 dan tata kelola pengetahuan untuk inovasi terbuka, penulis membentuk suatu rancangan model tata kelola pengetahuan proses inovasi produk yang dapat dilihat pada Gambar 2. Model Tata Kelola Pengetahuan Proses Inovasi Produk. Rancangan model ini memodifikasi sistem tata kelola COBIT 5.0 dengan menggunakan parameter tata kelola pengetahuan untuk inovasi terbuka serta menggunakan pemodelan proses IDEF untuk penggambaran proses manajemen pengetahuannya.

Proses manajemen pengetahuan digambarkan pada tahap penciptaan nilai pengetahuan dan inovasi. Proses ini terdiri dari 3 elemen utama yaitu perwujudan manfaat pengetahuan, optimasi risiko pengetahuan, dan optimasi sumber daya pengetahuan. Untuk melakukan pemodelan proses penciptaan pengetahuan di dalam tahap ini digunakan model notasi IDEF0 yang akan memberikan gambaran mengenai input, mekanisme, pemilik, serta hasil pengetahuan dari proses tersebut. Proses penciptaan pengetahuan yang dimaksudkan disini adalah pengetahuan yang diciptakan/dihasilkan pada proses inkubasi bisnis dan digambarkan dalam notasi IDEF0. Pada bagian berikutnya yaitu sistem tata kelola, dilakukan modifikasi terhadap sistem tata kelola COBIT 5.0 dengan menggunakan parameter tata kelola pengetahuan untuk inovasi terbuka.

Model Tata Kelola Pengetahuan Proses Inovasi Produk

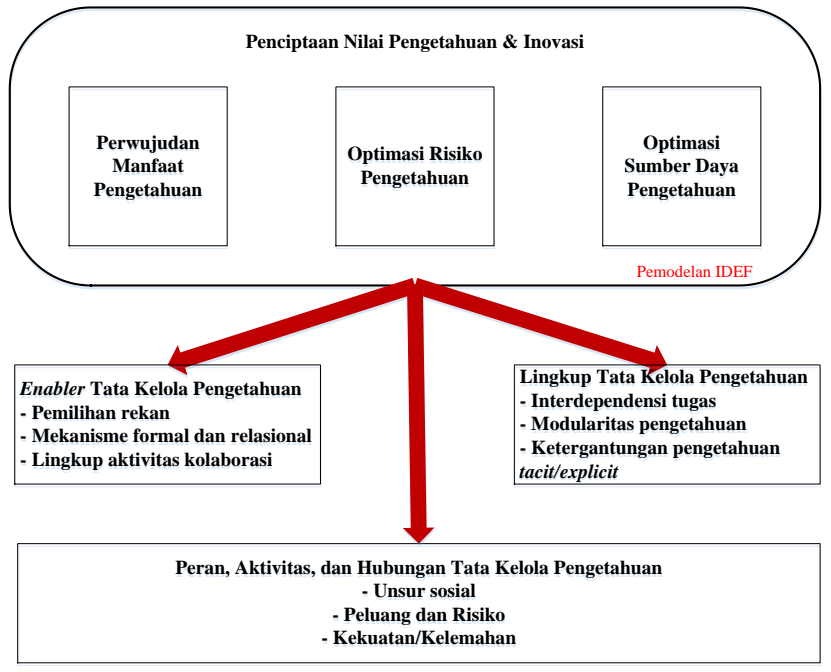

Gambar 2. Model Tata Kelola Pengetahuan Proses Inovasi Produk 


\section{KESIMPULAN DAN SARAN}

Berdasarkan seluruh tahap yang telah dilaksanakan dalam penelitian ini, maka didapat tiga komponen penyusun model tata kelola pengetahuan proses inovasi produk pada Techno Park, yaitu enabler tata kelola pengetahuan; lingkup tata kelola pengetahuan; peran, aktivitas dan tata kelola pengetahuan. Model tata kelola tersebut didapatkan berdasarkan sistem tata kelola COBIT 5.0 dan tata kelola pengetahuan berbasis inovasi terbuka guna melihat pencapaian level kapabilitas tata kelola pengetahuan melalui Process Assesment.

Namun, hasil penelitian ini masih memerlukan pengembangan lebih lanjut agar dapat memenuhi kebutuhan terkini proses inovasi produk yang ada di Techno Park, agar bisa lebih sesuai dengan kebutuhan masyarakat dan menciptakan kedaulatan inovasi di bidang teknologi. Selain itu, model dapat berpeluang untuk dijadikan penelitian lanjutan dengan fokus kepada Best Practices (BP) agar tata kelola pengetahuan proses inovasi produk di Techno Park bisa berjalan dengan lebih optimal.

\section{Daftar Pustaka}

Alavi, M., \& Leidner, D. (2001). Knowledge Management And Knowledge Management Systems: Conceptual Foundations And Research Issues. MIS Quarterly.

Choo, C. W. (1998). The Knowing Organization. How Organizations Use Information to Constract Meaning, Create Knowledge, and Make Decisions. New York: Oxford University Press.

Desouza, K., \& Awazu, Y. (2006). Engaging tensions of knowledge management control. Singapore Management Review.
Foss, N., \& Michailova, S. (2009). Knowledge Governance: Processes and Perspectives. Norfolk: Oxford University Press.

ISACA. (2012). A Business Framework for the Governance and Management of Enterprise IT. ISACA.

Moudi, M. (2011). Science and Technology Parks, Tools for a Leap into Future. Interdisciplinary Journal of Contemporary Research in Business.

Nonaka, I., \& Takeuchi, H. (1995). The KnowledgeCreating Company : How Japanese Companies Create the Dynamics of Innovation. Oxford: Oxford University Press.

Nonaka, I., \& Takeuchi, H. (2000). SECI, Ba and Leadership: a Unified. Long Range Planning, 33(1), 5-34.

Rahmatia, D. (2013). Perancangan Knowledge Management System untuk Mendukung Penerapan Malcolm Baldrige Criteria for Performance Excellence. Institut Teknologi Bandung.

Scarbrough, H., \& Edelman, L. (2004). The benefits and pitfalls of social capital: Empirical evidence from two organizations in the United Kingdom. British Journal of Management .

Tobing, P. L. (2007). Knowledge Management : Konsep, Arsitektur, dan Implementasi. Yogyakarta: Graha Ilmu.

Wickramasinghe, N. (2006). Knowledge Creation : A Meta Framework.

Wiig, K. (1999). Comprehensive Knowledge Management. Texas: Arlington. 